\title{
The Relationship between Demotivation and EFL Learners' English Language Proficiency
}

\author{
Rou-Jui Sophia Hu \\ Department of Applied Foreign Languages, Cheng Shiu University \\ Niaosong District, Kaohsiung 83347, Taiwan \\ Tel: 886-7-731-0606 ext 6215 E-mail: k0378@gcloud.csu.edu.tw
}

This research project was funded by a Cheng Shiu University Research Grant (CS-2-95-22).

Received: May 16, 2011

doi:10.5539/elt.v4n4p88

\author{
Accepted: June 13, 2011 \\ Published: December 1, 2011 \\ URL: http://dx.doi.org/10.5539/elt.v4n4p88
}

\begin{abstract}
To what extent does demotivation affect EFL learners' English language proficiency attainment? The present study addresses this question by investigating the relationship between technological institute EFL students' past demotivating factors and their English language proficiency. Although the role of demotivation in foreign language achievement has been examined, relatively few studies have been implemented to predict English language proficiency attainment from demotivating factors. Stepwise multiple regression analyses revealed that learning difficulties explained the most variance in the prediction of EFL learners' English language proficiency while language-specific anxiety was found to be the second most significant predictor variable. Of learning difficulties, "bad at memorizing vocabulary" entered into both equations, demonstrating the issue of insufficient vocabulary inventory of Taiwanese EFL technological college students. Language-specific anxiety was considered to be interrelated with learners' insufficient word bank in the present study.
\end{abstract}

Keywords: Demotivation, EFL Learners, Language-specific anxiety, English Language Proficiency

\section{Introduction}

Many a study has shown that motivation plays a significant role in attaining second/foreign language proficiency (Brown, 1981; Clement, Gardner, \& Smythe, 1981; Dornyei, 1990; Oxford, 1994; Schmidt, Boraie, \& Kassabgy, 1996; Ushioda, 1994). Motivation has been proved to be a crucial factor for determining the success of second/foreign language acquisition (Dornyei, 1990, 2001a, 2001b; Gardner, Lalonde, Moorcroft, \& Evers, 1985; Oxford \& Shearin, 1994; Scarcella \& Oxford, 1992; Warden \& Lin, 2000).

However, there also exist demotivating factors that impede learners' learning motivation and, hence lead to unsuccessful mastery of English language proficiency. According to Gorham \& Christophel (1992) and Christophel \& Gorham (1995), two-thirds of the demotivating factors pertinent to instructional communication are related with "teacher". Song (2005) also reported that the reasons why some motivated students become demotivated are multifaceted, but teachers played an important role in that process. Chang \& Cho (2003) reported on a study which investigated the demotivating factors of English language learning among Taiwanese junior high school students. Of the ninety-one essays students were asked to write, eight factors were summarized as the sources of demotivation; they were: 1 . learning difficulties; 2 . threats to self-worth; 3 . monotonous teaching; 4 . poor teacher-student relationship; 5. punishments; 6 . general and language-specific anxiety; 7. lack of self-determination; and 8. poor classroom management.

The above eight demotivating factors are utilized, in this study, to investigate Taiwanese technological college students' demotivating factors in relation to their English language proficiency. Because there has been few studies focusing on the relationship between demotivating factors and EFL learners' English language proficiency in an Asian EFL context, this study aims to investigate Taiwanese technological university students' demotivating factors to see how prior experience of learning English has demotivated them by applying correlational analyses and multiple regression analyses.

\section{Review of the Literature}

According to Dornyei (2001b), demotivation does not mean that all the positive influences that originally made up 
the motivational basis of a behavior have been annulled; rather, it is only the resultant force that has been dampened by a strong negative component. "Demotivation" concerns specific external forces that reduce or diminish the motivational basis of a behavioral intention or an ongoing action. A "demotivated" learner is someone who was once motivated but has lost his or her commitment/interest for some reason (Dornyei, 2001b).

The research on demotivation in instructional communication studies is mostly done by Gorham and Christophel. Gorham and Christophel (1992) tried to determine what factors were deemed as demotives by college students while they took introductory communication classes. The findings showed that teacher-related factors accounted for seventy-nine percent of all the responses. In 1995, Christophel and Gorham used the same questionnaire to detect demotives among another group of college students. The results were consistent with those from the previous findings. Gorham and Millette (1997) administered a further investigation based on Gorham's previous research. Their findings showed that teachers were more likely to attribute student demotivaiton to performance related factors while students attributed more of their demotivation to teacher behavior, such as poor presentational skills, and lack of enthusiasm.

In the field of L2 motivation research, Chamber's study (1993) was undertaken to explore demotivation among elementary students. The findings showed that teachers perceived the causes of demotivation differently from how students perceived them. Teachers perceived the causes of demotivation as related to a variety of reasons: psychological, attitudinal, social, historical, and geographical, except for themselves. Students, on the other hand, blamed their teachers for: not giving clear enough instructions, criticizing students, and shouting at them when they do not understand

Other studies also give further insight to student demotivation. Oxford (1998) asked the participants to recall their learning experiences over a period of five years. Four themes emerged from a content analysis of the data: 1 . The teacher's personal relationship with the students; 2 . The teacher's attitude towards the course or the material; 3 . Style conflicts between teachers and students; 4. The nature of the classroom activities. Ushioda (1998) asked twenty Irish learners of French to identify what they found to be demotivating in their L2-related learning experiences. She found that their responses targeted negative aspects of the institutionalized learning framework, rather than personal factors. Dornyei (1998b) categorized the following main demotivating factors: 1. the teacher; 2. inadequate school facilities; 3. reduced self-confidence; 4. negative attitude; 5. compulsory nature of L2 study; 6 . interference of another foreign language being studied; 7. negative attitude towards L2 community; 8. attitudes of group members; and 9. coursebook.

\section{Methodology}

\subsection{Participants}

Participants in this study are 467 freshmen students from a technological university in southern Taiwan. 241 male and 221 female students constitute the subjects of this study. They are from three colleges: 204 students from the engineering college, 201 students from the business college, and 47 students from the humanities college. All of the participants have taken formal English classes for six years - three years in junior high and three years in senior high. Among them, 150 students mention that they also go to intensive English programs while 295 students have never been to one.

\subsection{Instrument}

The instrument used to measure demotivating factors is based on a questionnaire composed of thirty-five questions. These thirty-five questions are drawn from the study of Chang \& Cho (2003) and the author's own investigation. The questions are classified into eleven parts: 1. learning difficulties; 2. threats to self-worth; 3. monotonous teaching; 4. poor teacher-student relationship; 5. punishment; 6. general and language anxiety; 7. lack of self-determination; 8. poor classroom management ( the above eight items are from Chang \& Cho (2003)); 9. theory not put into practice; 10. xenophobia; 11. inadequate English skills at matriculation (items 9 to 11 are from the author's investigation). The subjects were asked to read a statement and decide if they: (1) strongly disagree, (2) disagree, (3) neither agree nor disagree, (4) agree, or (5) strongly agree with each statement. Students were also asked to provide their background information such as: gender, major, whether they have taken intensive English programs before, and whether they have taken GEPT before.

The instrument used to measure students' English language proficiency is adopted from the GEPT-- General English Proficiency Test, one of the most accessible and widely used language proficiency tests in Taiwan (commissioned by the Taiwan Ministry of Education, 1999, and administered by the national Language Training and Testing Center since 2002). Because it is not feasible to demand that all participants take the GEPT at the same time, the alternate means for obtaining the subjects' English language proficiency scores is to conduct a simulated GEPT test- a 
grammar \& reading comprehension test (twenty multiple choice questions) and a listening comprehension test (twenty multiple choice questions).

Cronbach's alpha reliability coefficient for the questionnaire was calculated to determine the internal-consistency reliability, which shows .84. This shows that the questionnaire used in this study is a reliable measure. Pearson product-moment correlation analyses were run to explore the relationship between demotivating statements and students' English language proficiency.

\subsection{Data analysis}

Pearson product-moment correlation coefficients were used to assess the relationship between thirty-five demotivated statements and students' English language proficiency. The purpose of Pearson product-moment correlations is to determine whether there is a relationship or similarity between two variables by telling if correlation coefficient ( $r$ ) has matched its level of significance. The correlation coefficient $(r)$ varies between +1.00 and -1.00 . The higher the absolute value of the correlation coefficient, the stronger the relationship between two variables (Maple, 1982). However, a correlational analysis can be viewed as assessing the contribution of an independent variable, in isolation, to a dependent variable, it typically does not illuminate, in the optimal sense, the reality that most researchers want to study (Tatsuoka, 1973). Due to the situation that most phenomena involve multiple effects, multiple regression was used as a major analysis in this study.

Stepwise multiple regression is an important technique in finding the most significant predictor variables within each criterion variable. In the process of stepwise multiple regression, the predictor variables which account for the greatest amount of variance in a particular criterion variable are obtained. In this study stepwise multiple regression analysis is performed on both of the two criterion variables (grammar test and listening test). First, all the predictor items found to correlate at a specified level (e.g. .01 or less) of significance will be entered into the stepwise multiple regression equation. Then, a second stepwise multiple regression program will run with only those significant predictor items as input. In some cases, a predictor found to be significant in the first regression analysis is not significant in the second run. The results of the second multiple regression analysis are utilized to establish the final prediction equation for each of the criterion variables (Maple, 1982). In this study, $\mathrm{R}^{2}$, the amount of variance accounted for by the significant predictor variables entered in the multiple regression equation, will be used as an important measure of effect size (Cohen, 1992). The $\mathrm{R}^{2}$ of the last significant predictor variable entered indicates the total amount of variance accounted for by all the predictor variables that entered the equation at a significant level. Change in $\mathrm{R}^{2}$ shows how much of the variance accounted for $\mathrm{R}^{2}$ is due to the inclusion of the variable entered at that step. Beta weight equals the simple correlation of predictor and criterion variables, therefore providing a means of comparing the relative effects of each predictor variable on the criterion variable (Abbashar, 1977; Nie, 1970).

\section{Results}

The following section presents the results of Pearson correlations and stepwise multiple regression analysis.

\subsection{Correlational analysis}

From Table 1, it can be seen that five out of eleven predictor variables, namely, "Learning difficulties", "General and language-specific anxiety", "Threats to self-worth", "Monotonous teaching", "Punishment", are significantly correlated with both of the two criterion variables. Note that, the item "bad at memorizing vocabulary (LEARNDIFFITY 1)" is found to have the highest correlation coefficient with the listening test and the second highest correlation coefficient with the grammar test at .01 level of significance. It can be seen that vocabulary building is one of the major problems for technological college students. Also worthy of notice is the item related with general and language-specific anxiety - ANXIETY 26 is found to have the second highest correlation coefficient with the listening test and the third highest correlation coefficient with the grammar test. It is apparent that the anxiety felt by many students negatively influences their language learning experience and perhaps even their achievement (Ewald, 2007).

\subsection{Stepwise multiple regression analysis}

Multiple regression techniques is a statistical procedure in which scores on one or more variable (i.e. independent variable) are used to predict scores on another variable (i.e. dependent variable) (Bailey, Onwuegbuzie, \& Daley, 2000). In the present study, the 11 demotivated variables which consist of 35 demotivated statements comprise independent variables, while grammar test \& listening test represent dependent variables.

The four predictor items (demotivated statements) in this regression analysis account for 10.7 percent of the variance in the grammar test. The four predictor items come from three predictor variables in this study: learning difficulties, general and language-specific anxiety, and monotonous teaching (see Table 2). 
Using listening test as a criterion variable for assessing the predictive power of a set of independent variables in a multiple regression model, the proportion of variance explained indicates a medium effect size, since it exceeds $14 \%$. Table 3 shows that the six entered predictor items come from five predictor variables in this study: learning difficulties, punishment, monotonous teaching, general \&language-specific anxiety, and poor teacher-student relationship.

Table 2 shows that LEARNDIFFITY 2- “confused by English grammar" ( from the predictor variable of learning difficulties) explained the most variance $(5,8 \%)$ in grammar achievement; while in Table 3, LEARNDIFFITY 1 - " bad at memorizing vocabulary" ( from the predictor variable of learning difficulties) explained the most variance $(6.2 \%)$ in listening comprehension achievement test. In both equations, the first predictor items that enter into the equations are from the same predictor variable--- learning difficulties. Furthermore, among all predictor variables, learning difficulties has the most items (two items) entered into both equations. General and language-specific anxiety has one item entered into each equation, respectively, and so does monotonous teaching.

Four items entering grammar test equation explain $10.7 \%$ of the variance while six items entering listening test equation explain $14.4 \%$ of the variance. This result shows that students' grammar is, on average, poor, and is difficult to precisely classify their level of grammar competence ranging from excellent to poor. Thus, it results in the difficulty of analysis and likewise, lessens the predictive power.

\subsubsection{Summary of stepwise multiple regression analysis}

The stepwise multiple regression analyses for the two criterion variables include 9 different significant predictor items, from five predictor variables: learning difficulties, general \& language specific anxiety, monotonous teaching, poor teacher-student relationship, and punishment. Based upon the number of predictor items entering the sum total of the two regression equations, as well as the changes in $\mathrm{R}^{2}$ occurring when entered, the component variables of demotivating factors appear to be as follows, listed in descending order of importance:

1. Learning difficulties: with 4 items entering 2 equations (total changes in $\mathrm{R}^{2}=.166$ )

2. Anxiety \& language-specific anxiety: with 2 items entering 2 equations (total changes in $\mathrm{R}^{2}=.035$ )

3. Monotonous teaching: with 2 items entering 2 equations (total changes in $\mathrm{R}^{2}=.025$ )

4. Punishment: with 1 item entering 1 equation (total change in $\mathrm{R}^{2}=.012$ )

5. Poor teacher-student relationship: with 1 item entering 1 equation (total change in $\mathrm{R}^{2}=.009$ )

\section{Discussion}

\subsection{Learning difficulties}

Taiwanese technological college students are mainly recruited from vocational high schools. The difference between vocational high school students and senior high school students lies in the fact that the academic performance of vocational high school students is not as good as that of senior high school students ( $\mathrm{Hu}, 2007)$. This is due to the following two reasons. First, before they are admitted to high schools, both vocational high school students and senior high school students take the same high school entrance test, named Basic Competence Test (BCT). Those who score high on BCT mostly choose senior high schools to study; while those who do not perform well on the test usually choose to study at vocational high schools (http://www.bctest.ntnu.edu.tw/). Because English language is a required subject during secondary education, the English language proficiency achievement of senior high school students is, thus, mostly better than that of the students from vocational high schools. As well, the number of class hours devoted to English in senior high schools is usually twice those of vocational high schools. Therefore, it is not surprising to find that learning difficulties emerge as the first and foremost significant predictor variable (the most items entering into the equations with the largest total changes in $\mathrm{R}^{2}$ ) in this investigation.

Among the items pertinent to learning difficulties, the items that entered into equations are related with the following three aspects: vocabulary reciting, grammar translation, and listening comprehension. Note that, bad at memorizing vocabulary (LEARNDIFFITY 1) entered into both grammar test (at the fourth step) and listening test (at the first step) equations, respectively, indicating that insufficient vocabulary inventory among technological college students is an issue that Taiwanese English language researchers and teachers should take note of. Memorizing vocabulary is not the sole and only way to learn English language, but without sufficient vocabulary size, mastery of English language is utterly impossible. The impact of insufficient vocabulary size is immense in that it affects a learner's reading comprehension, writing skills, listening comprehension, and even speaking skills. How to help enlarge students' vocabulary inventory and keep them motivated to memorize vocabulary is an important task for Taiwanese English practitioners and researchers. 


\subsection{Anxiety and language-specific anxiety}

Anxiety and language-specific anxiety emerges as the second most important predictor variable with two items entering into two equations while both of the two items are closely related with language-specific anxiety. Limited vocabulary size and language-specific anxiety are interrelated. It is reasonable to find that students with deficient vocabulary inventory experience anxiety in their foreign language classrooms. A large number of studies (e.g., Elkhafaifi, 2005; Gregersen, 2003; Gregersen \& Horwitz, 2002; Horwitz, 1995; Horwitz, Horwitz, \& Cope, 1986; MacIntyre \& Gardner, 1989, 1991; Young, 1986) have emphasized the negative effects of anxiety in the classroom. Thus, to reduce the anxiety of foreign language learners, language teachers should be aware of avoiding undue tension for their students. Teaching methodologies aimed at reducing students' anxiety should be applied. For example, implementing small-group work to create higher comfort level in class is a good measure to consider.

\subsection{Monotonous teaching, punishment, and poor teacher-student relationship}

These three demotivating factors--monotonous teaching, punishment, and poor teacher-student relationship-- are all related to teachers, purely and directly. Monotonous teaching concerns teachers' teaching methodologies while punishment concerns teachers' classroom management which is inevitably one possible variable that leads to poor teacher-student relationship. Although these three variables (total change in $\mathrm{R}^{2}=.046$ ) contribute less to the prediction of criterion variables than do learning difficulties (total change in $\mathrm{R}^{2}=.166$ ), they still show a certain degree of detrimental influence on students' foreign language learning outcomes. This result showed that teachers played an important role in affecting students' learning process; if not careful, teachers can easily demotivate students to learn.

\section{Conclusion}

This study provided a greater understanding of demotivaing factors for EFL learning among Taiwanese technological institute students by applying stepwise multiple regression analysis. It found that learning difficulties preceded the rest of the predictor variables and accounted for the greatest amount of variance. Among the entered items pertinent to learning difficulties, lacking sufficient vocabulary inventory comes as the first and foremost significant demotivating factor. Insufficient vocabulary size has a detrimental impact on foreign language learning. Without sufficient vocabulary size, learners will never be able to command the English language effectively. Although learning difficulties are about students' own competence, rather than the teachers' competence or influence, how to enlarge Taiwanese technological institute students' vocabulary inventory is an issue that should draw Taiwanese English language practitioners and researchers' attention. Language-specific anxiety is the second most significant predictor variable among others. Learning difficulties and language-specific anxiety are interrelated. Students with a low word bank, bad grammar translation, or poor listening comprehension mostly experience anxiety in a foreign language classroom. Thus, how to reduce anxiety of EFL learners with learning difficulties is an important task for Taiwanese English language teachers. As for the other entered predictor variables for demotivation, monotonous teaching, punishment, and poor teacher-student relationship, teachers are definitely the one and only cause. As mentioned earlier, teachers have a crucial influence on EFL students' learning process. Providing any undue tension in a foreign language classroom should be strictly avoided.

\section{References}

Abbashar, A. W. (1977). Attitudinal and aptitudinal Factors and their factors and their relationship to learning English as a foreign language: A study of Arab students at Indiana university. Unpublished doctoral dissertation. Indiana University, Indiana. http://dx.doi.org/10.1016/S0346-251X(99)00064-0

Bailey, P., Onwuegbuzie, A., \& Daley, C. (2000). Using learning style to predict foreign language achievement at the college level. System, 28, 115-133

Brown, H. D. (1981). Affective factors in second language learning. In J. E. Alatis, H. B. Altman, \& P. M. Alatis (Eds.), The Second Language Classroom: Directions for the Eighties. New York: Oxford University Press. pp. 111-129

Chamber, G. N. (1993). Taking the 'd' out of demotivation. Language Learning Journal, 7, 13-16. http://dx.doi.org/10.1080/09571739385200051

Chang, S. M., \& Cho, C.H. (2003). Demotivating Factors in Foreign Language Learning. Selected Papers from the Twelfth International Symposium on English Teaching. Taipei: Crane Publishing. pp. 257-264

Christophel, D. M., \& Gorham, J. (1995). A test-retest analysis of student motivation, teacher immediacy, and perceived sources of motivation and demotivation in college classes. Communication Education, 44, 292-306

Clement, R., Gardner, R.C., \& Smythe, P. C. (1981). Social and individual factors in second language acquisition. 
Canadian Journal of Behavioral Science, 12, 293-302. http://dx.doi.org/10.1037/h0081081

Cohen, J. (1992). Statistical Power Analysis for the Behavioral Sciences. New York, John Wiley.

Dornyei, Z. (1990). Conceptualizing motivation in foreign language learning. Language Learning, 40, $46-78$

Dornyei, Z. (1998b, March). Demotivation in foreign language learning. Paper presented at the TESOL ' 98 Congress, Seattle, WA, USA.

Dornyei, Z. (2001a). New themes and approaches in second language motivation research. Annual Review of Applied Linguistics, 21, 43-59

Dornyei, Z. (2001b). Teaching and Researching Motivation. London: Longman.

Elkhafaifi, H. (2005). Anxiety and the true beginner-false beginner dynamic in beginning French and Spanish classes. Modern Language Journal, 89(2), 206-220

Ewald, J. D. (2007). Foreign language learning anxiety in upper-level classes: involving students as researchers. Foreign Language Annals, 40(1), 122-142

Gardner, R. C., Lalonde, R N., Moorcroft, R., \& Evers, F. T. (1985). Second language attrition: The role of motivation and use. London, Ontario: University of Western Ontario, Department of Psychology.

Gorham, J., \& Christophel, D. M. (1992). Students' perceptions of teacher behaviors as motivating and demotivating factors in college classes. Communication Quarterly, 40(3), 239-252

Gorham, J., \& Millette, D.M. (1997). A comparative analysis of teacher and student perceptions of sources of motivation and demotivation in college classes. Communication Education, 46(4), 245-261. http://dx.doi.org/10.1080/03634529709379099

Gregersen, T. (2003). To err is human: A reminder to teachers of language-anxious students. Foreign Language Annals, 36(1), 25-32

Gregersen, T., \& Horwitz, E. K. (2002). Language learning and perfectionism: Anxious and non-anxious language learners' reactions to their own oral performance. Modern Language Journal, 86, 562-570

Horwitz, E. K. (1995). Student affective reactions and the teaching and learning of foreign languages. International Journal of Educational Research, 23(7), 573-579

Horwitz, E. K., Horwitz, M. B., \& Cope, J. (1986). Foreign language classroom anxiety. Modern Language Journal, $70,125-132$

Hu, R. J. (2007). English language strategies among Taiwanese four-year technological students. Journal of SHU-TE University, 9(1), 1-9

MacIntyre, P. D., \& Gardner, R.C. (1989). Anxiety and second language learning: Toward a theoretical clarification. Language learning, 39, 251-275

MacIntyre, P. D., \& Gardner, R.C. (1991). Methods and results in the study of anxiety and language learning: A review of the literature. Language Learning, 41, 85-117

Maple, R. F. (1982). Social distance and the acquisition of English as a second language: A study of Spanish-speaking adult learners. Unpublished doctoral dissertation. The University of Texas at Austin, Austin, Texas.

Nie, N. (1970). Statistical Package for the Social Sciences. New York: Mc Graw-Hill.

Oxford, R. L. (1994). Where are we with language learning motivation? Modern Language Journal, 78, 512-514

Oxford, R. L. (1998, March). The unraveling tapestry: Teacher and course characteristics associated with demotivation in the language classroom. Demotivation in foreign language learning. Paper presented at the TESOL ' 98 Congress, Seattle, WA, USA.

Oxford, R. L., \& Shearin, J. (1994). Language learning motivation: Expanding the theoretical framework. Modern Language Journal, 78, 12-28. http://dx.doi.org/10.2307/329249

Scarcella, R., \& Oxford, R.L. (1992). The Tapestry of Language Learning: The Individual in the Communicative Classroom. Boston: Heinle \& Heinle.

Schmidt, R., Boraie, D., \& Kassabgy, O. (1996). Foreign language motivation: Internal structure and external connections. In Oxford R. (Ed.), Language learning motivation: Pathways to the new century. Honolulu, HI: University of Hawaii Press. pp. 9-70 
Song, Y. (2005). Motivation and demotivation in L2 learning. Sino-US English Teaching, 2(7), 79-81

Tatsuoka, M. M. (1973). Multivariate analysis in educational research. In Kerlinger, F.N. (Ed.), Review of Research in Education. Peacock. IL: Itasca. pp. 273-319

Ushioda, E. (1994). L2 motivation as a qualitative construct. Teanga, 14, 76-84

Ushioda, E., (1998). Effective motivational thinking: A cognitive theoretical approach to the study of language learning motivation. In E. A. Soler \& V. C. Espurz (Eds.), Current Issues in English Language Methodology. Spain: Universitat Jaume I. pp. 77-89

Warden, C. A., \& Lin, H. J. (2000). Existence of integrative motivation in an Asian EFL setting. Foreign Language Annals, 33(5), 535-547

Young, D. J. (1986). The relationship between anxiety and foreign language oral proficiency ratings. Foreign Language Annals, 19, 439-445. http://dx.doi.org/10.1111/j.1944-9720.1986.tb01032.x

Table 1. Correlations of demotivating factors and English language proficiency variables

\begin{tabular}{|c|c|c|}
\hline \multirow[t]{2}{*}{ Demotivating factors } & \multicolumn{2}{|c|}{$\begin{array}{ll}\text { English } & \text { language } \\
\text { variables }\end{array}$} \\
\hline & Grammar Test & Listening Test \\
\hline \multicolumn{3}{|l|}{ Learning Difficulties } \\
\hline Bad at memorizing vocabulary (LEARNDIFFITY1) & $.22 * *$ & $.24 * *$ \\
\hline Confused by English grammar (LEARNDIFFITY2) & $.24 * *$ & $.15^{* *}$ \\
\hline English writing is hard for me ( LEARNDIFFI TY3) & $.20 * *$ & $.12 *$ \\
\hline English phonetic is hard for me (LEARNDIFFI TY4) & $.11^{*}$ & $.18^{* *}$ \\
\hline Confused by English pronunciation (LEARNDIFFI TY5) & $.10 *$ & $.16^{* *}$ \\
\hline Poor listening comprehension (LEARNDIFFI TY6) & $.14^{* *}$ & $.24 * *$ \\
\hline $\begin{array}{l}\text { Having problems in comprehending sentences (LEARNDIFFI } \\
\text { TY7) }\end{array}$ & $.15^{* *}$ & $.13^{* *}$ \\
\hline $\begin{array}{l}\text { Having problems in reading comprehension ( LEARNDIFFI } \\
\text { TY8) }\end{array}$ & $.19^{* *}$ & $.20 * *$ \\
\hline \multicolumn{3}{|l|}{ Threats to Self-worth } \\
\hline $\begin{array}{l}\text { Practicing pronunciation in front of my classmates is } \\
\text { embarrassing because I might be made fun of by them (TH } \\
\text { REAT 9) }\end{array}$ & $.16^{* *}$ & $.23^{* *}$ \\
\hline $\begin{array}{l}\text { When compared with my siblings by my parents, I feel } \\
\text { irritated (THREAT10) }\end{array}$ & $.09^{*}$ & .08 \\
\hline $\begin{array}{l}\text { I feel that my teachers only like those who earn good grades } \\
\text { in tests. If I don't, I'll be looked down upon.(THREAT 11) }\end{array}$ & $.16^{* *}$ & $.18^{* *}$ \\
\hline $\begin{array}{l}\text { I was mocked by my classmates when I fail my tests (TH } \\
\text { REAT12) }\end{array}$ & $.15^{* *}$ & $.18^{* *}$ \\
\hline \multicolumn{3}{|l|}{ Monotonous Teaching } \\
\hline Boring lecturing (MONO 13) & $.11^{*}$ & $.18^{* *}$ \\
\hline Repetition of listening practice (MONO 14) & $.15^{* *}$ & $.12 *$ \\
\hline $\begin{array}{l}\text { Cramming and reciting vocabulary and sentence patterns } \\
\text { ( MONO 15) }\end{array}$ & $.12 * *$ & $.10^{*}$ \\
\hline Fast lecturing, leaving no time to catch up (MONO 16) & --- & $.13 * *$ \\
\hline \multicolumn{3}{|l|}{ Poor Teacher-student Relationship } \\
\hline Teachers' impatience terrifies me (PORTEASTURELA 17) & --- & --- \\
\hline
\end{tabular}


Teachers' humiliation on low achievers terrifies me --(PORTEASTURELA 18)

Disagree with teachers' attitude in teaching --(PORTEASTURELA 19)

Only high achievers gain teachers' appraisal .094* (PORTEASTURELA 20)

Teachers' mocking and scolding on my poor performance .--irritates me (PORTEASTURELA 21)

Teachers are easy to become emotional (PORTEASTURELA --22)

\section{Punishment}

I have been punished because of my poor performance $.14^{* *}$ (PUNISH 23)

Being punished in public really humiliates me (PUNISH 24) . $.15^{* *}$

\section{General andLlanguage-specific Anxiety}

It embarrassed me when I was asked to speak in front of $19^{* *}$ others (ANXIETY 25)

I am nervous when I am asked to read English out loud in $.20^{* *}$ class(ANXIETY 26)

Teachers' teaching method and their attitude cause my anxiety $.14^{* *}$ (ANXIETY 27)

\section{Lack of Self-determination}

I am forced to go to intensive English programs by my --parents (LASELDETER 28)

I am forced to learn English at my leisure time --(LASELDETER 29)

\section{Poor Classroom Management}

The class is always in disorder, which affects my performance --in class (POORCLMANA 30 )

My classmates are not into studying, which affects my --performance in class (POORCLMANA 31)

\section{Theory not Put into Practice}

What I have learned at school is not useful (THEONOPRAC --32)

The content of the textbooks is not interesting or pragmatic --(THEONOPRAC 33)

\section{Xenophobia}

I do not like foreigners (XENOPHO 34)

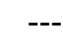

Inadequate English Skills at Matriculation

The school that I previously went to did not consider English --as an important tool for communication (INADENG 35)

$$
* \mathrm{p}<\overline{0.05}
$$


Table 2. Stepwise multiple regression model for predicting grammar test $\mathrm{t}^{\mathrm{a}}$

\begin{tabular}{lllllll}
\hline Variable & $\begin{array}{l}\text { Beta } \\
\text { Weight }\end{array}$ & F-to-enter & $\mathrm{P}$ & Multiple R & $\mathrm{R}^{2}$ & $\begin{array}{l}\text { Change in } \\
\mathrm{R}^{2}\end{array}$ \\
\hline $\begin{array}{l}\text { Learning Difficulties } \\
\text { LEARNDIFFITY 2 } \\
\text { General and }\end{array}$ & .159 & 27.394 & .001 & .243 & .059 & .059 \\
$\begin{array}{l}\text { Language-specific } \\
\text { Anxiety }\end{array}$ & & & & & & \\
$\begin{array}{l}\text { ANXIETY 26 } \\
\begin{array}{l}\text { Monotonous } \\
\text { Teaching }\end{array}\end{array}$ & .119 & 19.821 & .015 & .289 & .083 & .024 \\
$\begin{array}{l}\text { MONO 14 } \\
\text { Learning Difficulties }\end{array}$ & .116 & 15.657 & .012 & .312 & .097 & .014 \\
LEARNDIFFITY 1. & .112 & 13,068 & .028 & .328 & .107 & .010 \\
\hline
\end{tabular}

${ }^{\text {a }}$ Model, $\quad$ Adjusted $\mathrm{R}^{2}=0.099$

Table 3. Stepwise multiple regression model for predicting listening test ${ }^{\mathrm{b}}$

\begin{tabular}{|c|c|c|c|c|c|c|}
\hline Variable & $\begin{array}{l}\text { Beta } \\
\text { Weight }\end{array}$ & F-to-enter & $\mathrm{P}$ & Multiple R & $\mathrm{R}^{2}$ & $\begin{array}{l}\text { Change in } \\
\mathrm{R}^{2}\end{array}$ \\
\hline \multicolumn{7}{|l|}{ Learning Difficulties } \\
\hline LEARNDIFFITY 1 & .161 & 28.909 & .001 & .249 & .062 & .062 \\
\hline LEARNDIFFITY 6 & .130 & 23.434 & .007 & .312 & .097 & .035 \\
\hline \multicolumn{7}{|l|}{ Monotonous Teaching } \\
\hline MONO 13 & .164 & 18.374 & .001 & .335 & .112 & .015 \\
\hline $\begin{array}{ll}\text { General } & \text { and } \\
\text { Language-specific } & \\
\text { Anxiety } & \end{array}$ & & & & & & \\
\hline ANXIETY 25 & .105 & 15.227 & .031 & .351 & .123 & .011 \\
\hline \multicolumn{7}{|l|}{$\begin{array}{l}\text { Poor Teacher-student } \\
\text { Relationship }\end{array}$} \\
\hline PORTEASTURELA 17 & -.145 & 13.172 & .006 & .363 & .132 & .009 \\
\hline \multicolumn{7}{|l|}{ Punishment } \\
\hline PUNISH 24 & .123 & 12.124 & .014 & .380 & .144 & .012 \\
\hline
\end{tabular}

${ }^{\mathrm{b}}$ Model, $\quad$ Adjusted $\mathrm{R}^{2}=0.132$ 